\title{
Impact of Urbanization on Vegetation: a Survey of Peshawar, Pakistan
}

\author{
Kashif Ali ${ }^{1,2}$, Naveed Akhtar ${ }^{2}$, Muhammad Shuaib ${ }^{3}$, Sajjad Ali ${ }^{4}$, Abdul Ghaffar ${ }^{5 *}$, \\ Muzammil Shah $^{6}$, Aimal Khan ${ }^{7}$, Firasat Hussain ${ }^{8}, Z_{\text {Zahid Khan', Imdad Kaleem }}{ }^{10}$, \\ Arif Nazir ${ }^{11}$, Munawar Iqbal ${ }^{11 * *}$
}

\author{
${ }^{1}$ Institute of Ecology and Geobotany, School of Ecology and Environmental Science Yunnan University, \\ NO.2 North Cuihu road, Kunming, Yunnan, 650091, PR. China \\ ${ }^{2}$ Department of Botany, Islamia College Peshawar, Pakistan \\ ${ }^{3}$ School of Ecology and Environmental Science, Yunnan University, NO.2 North Cuihu road, \\ Kunming, Yunnan, 650091, PR. China \\ ${ }^{4}$ Department of Botany, Bacha Khan University Charsadda, Pakistan \\ ${ }^{5}$ Department of Biochemistry, Government College University, Faisalabad, Pakistan \\ ${ }^{6}$ Department of Biological Sciences, King Abdulaziz University, Jeddah-21589, Saudi Arabia \\ ${ }^{7}$ State key Laboratory of Plant Genomics, Institute of Genetics and Developmental Biology, \\ Chinese Academy of Science, Beijing 100101, China \\ ${ }^{8}$ Department of Microbiology, University of Swabi Pakistan \\ ${ }^{9}$ College of Life Sciences, Northwest University, Xian China \\ ${ }^{10}$ Department of Biosciences, COMSATS Institute of Information Technology, Islamabad, Pakistan \\ ${ }^{11}$ Department of Chemistry, The University of Lahore, Lahore, Pakistan
}

Received: 8 August 2017

Accepted: 28 March 2018

\begin{abstract}
This paper analyzes a phytosociological study and urbanization in Regi Model Township (RMT) in Peshawar, Pakistan. The study was conducted during spring 2015 and a total of 32 plant species were identified belonging to 19 families. The Asteraceae family had the highest number of species 5 spp. while Fabaceae, Polygonaceae, and Brassicaceae had 3 spp. each. Poaceae and Solanaceae had 2 spp. each, while Plantiginaceae, Malvaceae, and Caryophyllaceae had 1 spp. each. In zone 1, a total of 27 plant species were reported in which the Cynodon-Carthamus-Datura community was established on the basis of the importance value index. The soil of this zone was silty clay loamy in texture with a $\mathrm{pH}$ of 8.3 , nitrogen $0.017 \%$, phosphorus $7.4 \%$, and organic matter $(\mathrm{OM})$ was $(0.34 \mathrm{ppm})$. In zone 2, a total of 23 plant species were reported, and the Xanthium-Parthenium-Cyperus community was established. The soil in this zone was loamy sandy with $\mathrm{pH}$ of 8.1 , nitrogen $0.020 \%$,
\end{abstract}

*e-mail: aghaffaruaf@yahoo.com

**e-mail: bosalvee@yahoo.com 
phosphorus 3.1\%, and $\mathrm{OM}$ 0.04. In zone 3 a total of 21 plants species were reported and the Cynodon-Prosopis-Xanthium community was established. The soil in this community was silty clay loamy having a $\mathrm{pH}$ of 8.1 , nitrogen $0.034 \%$, phosphorus $4.1 \%$, and $\mathrm{OM}$ of $(0.068 \mathrm{ppm}) \%$. In zone 4 , a total of 13 plant species were recorded and the Xanthium-Lepidium-Amaranthus community was established. The soil in this zone was silty clay loamy with a $\mathrm{pH}$ of 8.3 , nitrogen $0.029 \%$, phosphorus $6.2 \%$, and $\mathrm{OM} 0.058 \%$, and similarly in zone 5 , a total of 11 plant species were recorded in the area where the Cynodon-Parthenium-Cyperus community was established. The soil in this community was loamy sand having a $\mathrm{pH}$ of 8.1 , nitrogen $0.002 \%$, phosphorus $3.1 \%$, and $\mathrm{OM}(0.03 \mathrm{ppm})$. The construction work at RMT was causing the extinction of vegetation and there would be no more wild vegetation in the near future in that particular area.

Keywords: phytosociology, urbanization, construction, plant species, vegetation

\section{Introduction}

Rapid urbanization has excessive stress on natural resources [1-4] and is one of the main and most powerful anthropogenic activities of humans [5-7]. Protection of the environment and vegetation is an important global issue [8-11]. Related with other various industries like construction, is one of the main sources of pollution including air and water pollution [12-14]. Construction of buildings has direct and indirect effects on humans and vegetation. The process of urbanization drastically affects the environmental conditions and has been noted worldwide [15-18].

Since 2007, global urbanization has grown so rapidly that the majority of people have preferred to live in urban regions compared to rural regions [19-22]. Consequently, the urban regions were converted into main customers of energy consumption and carbon production. Urban regions are limited to $2 \%$ of the total global surface area, but are responsible for $>75 \%$ of energy consumption and carbon emissions [23-27]. Studies suggest that various factors responsible for energy consumption and carbon emissions may be economic growth, industrial restructuring, and many other factors [27-29]. Urbanization results in the accumulation of individuals and commercial events and hence promotes global environmental problems [29-32]. The output of construction is pollution, which includes harmful gases, noise, dust, and liquid waste. Knowledge and awareness are the two main factors that strengthen the sustainability movement [33]. Phytosociology is the branch of science that deals with plant communities, their composition and development, and the relationships between the species within them. It is a branch of plant ecology that explains the relationship of plant species among themselves and in a community [34-35]. The relationship between soil features and vegetation is directly related to each other in that they become indicative of each other. The habitat provided by the various ecological conditions would give permission to adopt their selves, thus the soil-plant relationship becomes so close that plants reveal the ecological situation of the inhabited locality.

\section{Material and Methods}

\section{Study Area}

The RMT is located at a distance of about $15 \mathrm{~km}$ northwest of Peshawar Cantonment. The site is enclosed between Warsak Jamrud Link Road in the northwest, Takhta beg Khawarin in the south, Warsak Gravity Canal in the northeast, and Warsak Lift Canal in the southwest. In 1989 the Peshawar Development Authority (PDA) prepared the concept of RMT to address the housing needs of government employees - especially officials of subordinate formations. Two character roads divide the RMT's into five zones, with each zone having approximately 315 hectares ( 800 acres).

Five study sites were selected in the RMT area for phytosociological investigations. The sites were selected on the basis of physiognomy in order to get an accurate image of vegetation of the whole area. Expeditions were conducted to five sites in spring 2015 following standard locality procedures [36]. Sampling was carried out systematically using the quadrat method. A quadrat size of $4 \times 4$ m was used throughout the study. Sampling was started at the initial margins of each zone and quadrats were laid onward after every $100 \mathrm{~m}$ distance. Species data, including cover, frequency, and density was recorded from the sites following Curtis and Cottam [37]. The collected specimens was pressed, dried, and mounted on standard herbarium sheets. The specimens were then identified with the help of Flora of Pakistan [38]. The voucher specimens were deposited into the herbarium at the Department of Botany, Islamia College University Peshawar, KPK, Pakistan. Composite soil samples were taken from all quadrats of each study site and physico-chemical analyses was conducted at the Agricultural Research Institute in Tarnab, Peshawar. The soil parameters analyzed included organic matter $(\mathrm{OM}), \mathrm{pH}$, saturation, texture, phosphorus (ppm), and potassium (ppm). The abovementioned parameters were calculated using the following formulae: 
Density

$\frac{\text { Density }}{m 2}=\frac{\text { Total number of plant species in all Quadrats }}{\text { Area Sampled }}$

Relative Density (\%)

Relative Density $=$ $\frac{\text { Density of individual species }}{\text { Total Density of all Species }} \times 100$

Frequency (\%)

Frequency $=$

$\frac{\text { Number of Quadrats in which species present }}{\text { Total number of Quadrats }} \times 100$

Relative Frequency (\%)

Relative Frequency $=$

$\frac{\text { Frequency Value of single species }}{\text { Total Frquency }} \times 100$

Importance Value

Importance Value $=$

Relative Density + Relative Frequency + Relative Cover 3

\section{Results and Discussion}

A phytosociological study was conducted in RMT in spring 2015 and a total of 32 plant species were identified belonging to 20 families (Fig. 1). Asteraceae had the highest number of species $5 \mathrm{spp}$. (Carthamus oxyacanthus L., Parthenium hysterophorus L., Sonhcus asper L., Conyza bonariensis (L) Dunal. and Xanthium strumarium L.) followed by Fabaceae ( Vicia faba L. Melilotus indicus (L.). All Prosopis juliflora (SW) DC Polygonaceae (Rumexdentatus



Fig. 1. Chart showing the percentage of species represented by different families.
D. DON Polygonum plebeium R.Br. Eclipta alba L.), and Brassicaceae having 3 species (Malcolmia africana (L.) R. Br. Coronopus didymus (L.) Sm., Lepidium vergincum L.). Poaceae, Amaranthaceae and Solanaceae had two species each (Cynodondactylon L.Pers., Setaria viridis (L.)P.Beauv.), (Achyranthes aspera L., Amaranthus viridis L.), (Daturaalba L., Withania somnifera (L.) Dunal.) respectively while Plantiginaceae, Malvaceae, Apiaceae, Apocynaceae, Cyperaceae, Primulaceae, Ranunculaceae, Rhamnaceae, Zygophyllaceae, Papaveraceae, Oxalidaceae, Malvaceae and Caryophyllaceae had single species each (Plantago lanceolata L.), (Malva neglecta Wallr.), (Scandix pectin veneris L.), (Calotropis procera R.Brown.), (Cyperusrotundus L.), (Anagallis arvensis L.), (Ranunculus muricatus L.), (Ziziphus jujube Mill.), (Fagoniacretica Linn.), (Fumariaindica L.), (Oxalis corniculataL.), (Malva neglecta Wallr.), (Stellaria media L.), respectively.

\section{Vegetation of Zone 1}

A total of 27 plant species were reported in this zone. Of the 27 recorded species there were 25 herbs, $1 \mathrm{shrub}$, and 1 tree. Asteraceae had the highest number of species (4 spp.), followed by Polygonaceae with (3 spp.), and Brassicaceae, Fabaceae, and Poaceae with 2 spp. each. While the remaining families (i.e., Cyperaceae, Amaranthaceae, Solanaceae, Apocynaceae, Apiaceae, Primulaceae, Ranunculaceae, Rhamnaceae, Zygophyllaceae, Papaveraceae, Oxalidaceae, Caryophyllaceae, Malvaceae, and Plantaginaceae) by (1spp.) each (Fig. 2). On the basis of the importance value index the following community was established. The soil in this community was silty clay loamy having $\mathrm{pH}$ of 8.3 , nitrogen $0.017 \%$, phosphorus $7.4 \%$, and OM 0.34\%. Cynodon (33.7), Carthamus (16.4) and Datura (16.0) showed highest IVI. Besides these three dominated species, Cynodon dactylon occurs on almost all soil types [39].

\section{Overgrazing and Cutting in Zone 2}

Xanthium strumarium and Parthenium hysterophorus are dominant plant species of this zone. Ziziphus and Prosopisjuliflora were tree noticed in zone 2. The soil in this community was loamy sand with $\mathrm{pH}$ of 8.1 , nitrogen $0.020 \%$, phosphorus 3.1 , and $\mathrm{OM}$ of 0.04 . The major issue of this zone is rampant grazing of cattle in this area. Over-grazing has many negative effects including soil erosion and loss of biodiversity. The plants of this zone face many threats such as overgrazing, overexploitation, and fuel wood collection, and the same issues were also reported by Habibul hassan et al. [40]. Ziziphus jujuba were utilized for fuel correspondingly, the result of Ibrar et al. [41] were also lined with our mention report. Grazing animals changed the composition of species, distribution of biodiversity, and biomass. The soil and plants that are trodden 

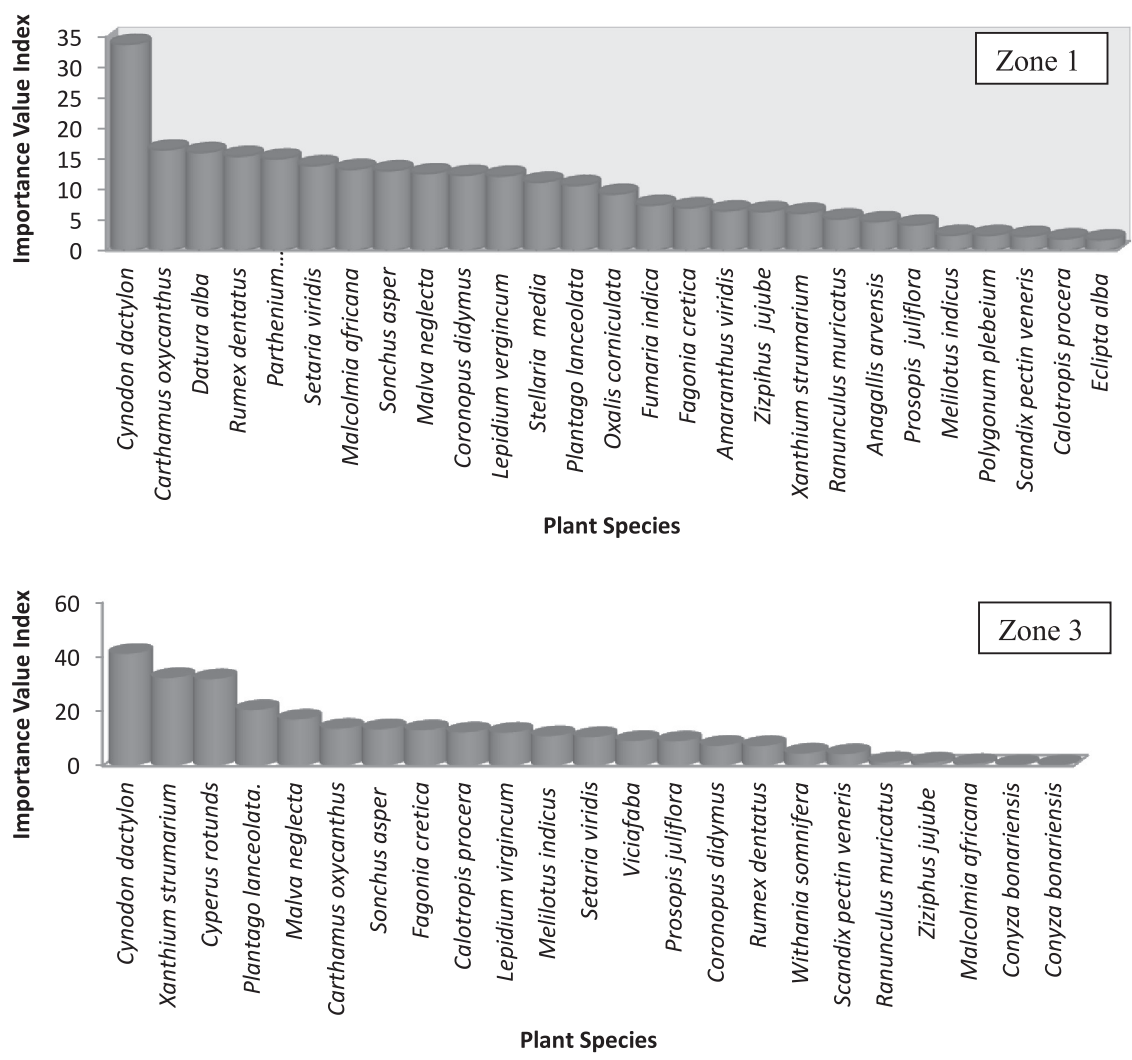

Fig. 2. Species in zones 1 and 3.

upon under animal feet sustain severe damage. The neighboring inhabitants of the locality totally depend upon these plants for fuel. We noticed the indiscriminate chopping of plants by people of all ages, and once these trees are cut down there is nothing to protect the soil.
Urbanization in Zone 3

Asteraceae, Brassicaceae, and Fabaceaewas are represented by 3 species each. Poaceae were represented by 2 species, while the reaming families, i.e.,
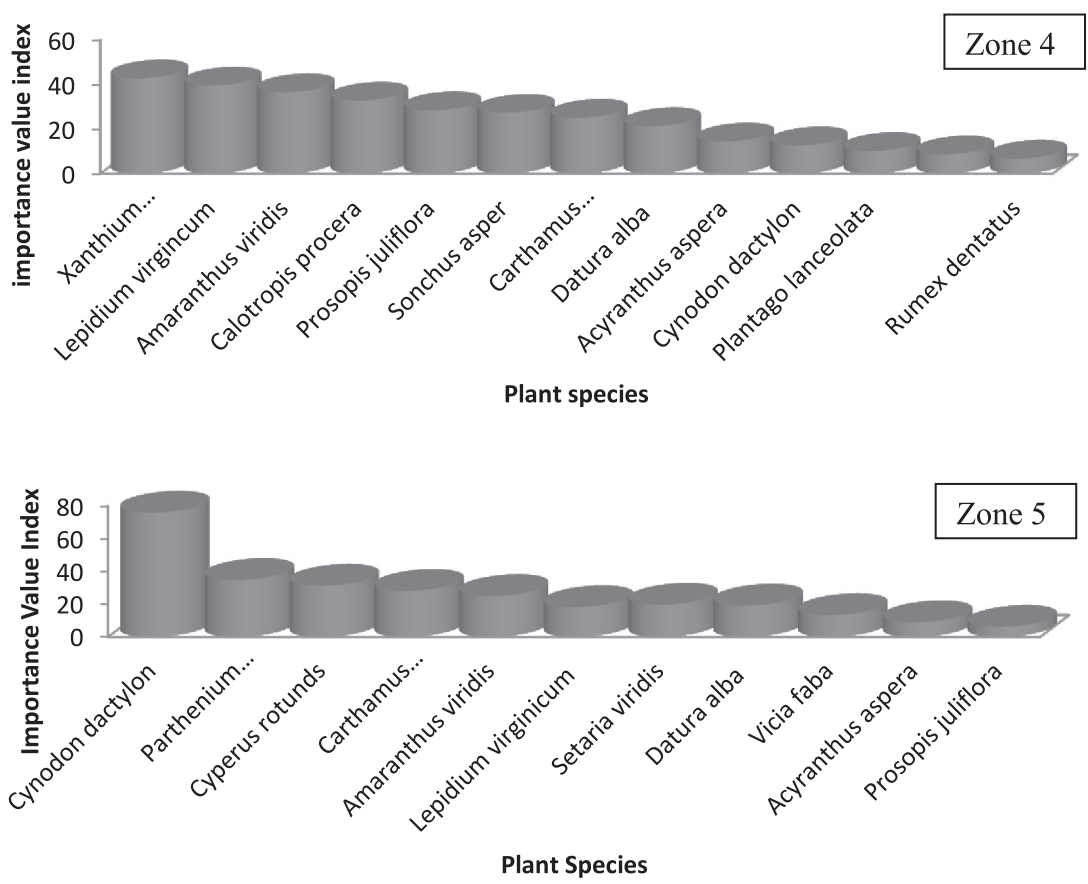

Fig. 3. Species in zones 4 and 5. 
Cyperaceae, Amaranthaceae, Solanaceae, Apocynaceae, Apiaceae, Primulaceae, Ranunculaceae, Rhamnaceae, Zygophyllaceae, Papaveraceae, Oxalidaceae, Caryophyllaceae, Malvaceae, and Plantaginaceae by (1 spp.) each. A total of 23 plant species were reported from this zone: 20 herbs, 2 trees, and 1 shrub. Malik et al. [42] reported these communities, which are in agreement with the present result.

A total of 22 plant species were reported in this zone. Of the 22 recorded species there were 20 herbs, 1 shrub, and 1 tree. Asteraceae was represented by 4 species followed by Fabaceae and Brassicaceae with 3 species each. While the remaining families (Cyperaceae, Amaranthaceae, Solanaceae, Apiaceae, Malvaceae, Polygonaceae) by (1 sp) each and in this zone massive construction projects were in progresses (Fig. 2). Various markets have been built to sell articles of daily use. A magnificent mosque and beautiful family park have been constructed in Zone 3. The rising population is driving the expansion of urban areas. The growth of cities may cause biodiversity to decrease a large area of natural habitat on which many plant species depend. The construction is responsible for using a large volume of natural resources and it generates a great amount of pollution; the same is true in the present research. Although there are many causes of habitat loss, urbanization has been shown to be one of the most damaging in terms of number of plant species loss or threatened loss. The construction work will cause the extinction of this vegetation. The environmental consequences of urbanization include urban heat, a phenomena of increased atmospheric and surface temperature occurring in urban area than in surrounding rural areas because of heavy traffic and industries. The same results have also been reported by Voogt and Oke [43]. Cynodon dactylon, Prosopis juliflora, and Xanthium strumarium has the highest importance value found in Zone 3. Cyperusrotundus, Viciafaba, and Plantago lanceolata are some other common species of Zone 3, with dactylonoccurs on almost all soil types Ahmad et al. [39]

\section{Urbanization in Zone 4}

A total 13 plant species were reported in this zone. Of the 13 recorded species there were 11 herbs, 1 shrub, and 1 tree. Asteraceae was represented by 4 species, while the reaming families' (Poaceae, Solanaceae, Apocynaceae, Amaranthaceae, Brassicaceae, Polygonaceae, Plantaginaceae, and Fabaceae) were by one species each. The soil in this community was silty clay loam with $\mathrm{pH}$ of 8.3 , nitrogen $0.029 \%$, phosphorus 6.2 , and $\mathrm{OM} 0.058$.

On the basis of IVI, Xanthium, Lepidium, and Amaranthus are the dominant species of Zone 2. With few exceptions, trees are completely absent due to cutting on a large scale. This zone is floristically very poor as compared to Zone 1. Ali et al. [44] also reported from the Mardan community district a resemblance to the present findings. In this zone urbanization is also at peak, due to which the plant species reduce their numbers. Urbanization leads to reduction of green areas in urban society. Due to construction and urbanization the loss of native species occurs, which has greatly changed biodiversity (Fig. 3). The expansion of cities due to urbanization increases the loss of biodiversity in study areas, and the number of native flora has fallen rapidly.

\section{Urbanization Planning in Zone 5}

In the near future there is a slight possibility of rapid construction despite the fact that roads have been constructed in this zone. In case of undertaking construction in this zone the native flora will become extinct. Overgrazing and logging have reduced this zone into a wasteland, but the relics of the chopped off trees can easily be seen. This zone is also exposed to heavy browsing and grazing. A total 12 plant species were reported in this zone. Of the 12 recorded species there were 11 herbs and 1 tree. Asteraceae, Poaceae, Fabaceae, and Amaranthaceae were represented by 2 species each, followed by Brassicaceae, Cyperaceae, and Solanaceae represented by 1 species (Fig. 3). The soil in this community was loamy sand with $\mathrm{pH}$ of 8.1, nitrogen $0.002 \%$, phosphorus 3.1, and OM 0.03.

The construction work in RMT will cause the extinction of vegetation. The vegetation that are extant there will be no more in the near future. Cynodon dactylon occurs on almost all soil types Ahmad et al. [39] since the cities are an important habitat for an array of physical, economic, social, political, and cultural capitals. Therefore, there is a need to think carefully about the nature, operation, and forms of cities - particularly in respect to the challenging issue of sustainability and the current scenario of environmental issues [45-55] also demand such practices. Urbanization is a danger to climate change and resultantly, biodiversity and natural habitat loss, air pollution exceeding safe limits, and urban flooding may change [56-68].

\section{Conclusions}

The rising human population is driving the expansion of urban areas. The growth of cities may cause biodiversity to decline a large area of natural habitat on which many plant species depend. Although there are many causes of habitat loss, urbanization has been shown to be one of the most damaging in terms of the number of plant species loss or threatened loss. Construction work will cause the extinction of this vegetation. The outcome of this research can help organizations and managers prepare appropriate plans and also increase information about the pattern construction area through awareness programs and training. More research is needed to investigate 
the on-site sustainable performance measurements using identified environmental impacts in advance.

1) Urbanization leads to reduction of green areas in urban areas.

2) Due to construction and urbanization the loss of native species occurs, which greatly changes biodiversity.

Future recommendations:

1) The government, professional bodies, and private sector need to start several programs in order to increase knowledge and awareness of construction practitioners.

2) Government needs to apply a series of measures specifically planned to protect the native flora of the study area.

3) Reducing tree cutting may increase the conservation of native flora.

4) Plans may include a ban on grazing or it may be reduced to a limited extent so as to provide a chance for the survival of herbaceous plants.

\section{Acknowledgements}

The reported work is the output of the Kashif Ali Research group. Dr. Munawar Iqbal and Dr. Arif Nazir handled the data interpretation, writing, and publication.

\section{Conflict of Interest}

The authors declare no conflict of interest.

\section{References}

1. LI G.Y., CHEN S., YAN Y., YU C. Effects of Urbanization on Vegetation Degradation in the Yangtze River Delta of China: Assessment Based on SPOT-VGT NDVI. J. Urban Plan. Dev. 141, (4), 1, 2014.

2. HAI T., WEN-CHENG P., CHANG-FENG C., JIANPING X., WEN-JUN H. Remediation of acid mine drainage based on a novel coupled membrane-free microbial fuel cell with permeable reactive barrier system. Pol. J. Environ. Stud. 25, (1), 107, 2016.

3. KWAŚNY J., BALCERZAK W. Sorbents used for biogas desulfurization in the adsorption process. Pol. J. Environ. Stud. 25, (1), 37, 2016.

4. NIE F., ZHOU Y., LIU R., LIU Z., HUANG, D. Pollutant removal and PCR-DGGE analysis of microbial community structural changes in an integrated vertical-flow constructed wetland. Pol. J. Environ. Stud. 25, (2), 709, 2016.

5. DAWSON R.J., HALL J.W., BARR S.L., BATTY M., BRISTOW A.L., CARNEY S., DAGOUMAS A., EVANS S., FORD A., HARWATT H., KÖHLER J., TIGHT M.R., WALSH C.L., ZANNI A.M. A blueprint for the integrated assessment of climate change in cities. Tyndall Working Paper 129, 26, 2009.

6. HUSSAIN S., NAEEM M., CHAUDHRY M.N. Estimation of residual antibiotics in pharmaceutical effluents and their fate in affected areas. Pol. J. Environ. Stud. 25 (2), 607, 2016.

7. KALAJI H.M., SYTAR O., BRESTIC M., SAMBORSKA I.A., CETNER M.D., CARPENTIER C. Risk assessment of urban lake water quality based on in-situ cyanobacterial and total chlorophyll-a monitoring. Pol. J. Environ. Stud. 25 (2), 655, 2016.

8. JAFARINEJAD S. Control and treatment of sulfur compounds specially sulfur oxides (SOx) emissions from the petroleum industry: a review. Chem. Int. 2, 242, 2016.

9. ABEBE A., CHANDRAVANSHI B.S., DEBEBE A., Assessment of essential and non-essential metals in popcorn and cornflake commercially available in Ethiopia. Chem. Int. 3, 268, 2017.

10. IQBAL M., Vicia faba bioassay for environmental toxicity monitoring: a review. Chemosphere 144, 785, 2016.

11. UKPAKA C., Predictive model on the effect of restrictor on transfer function parameters on pneumatic control system. Chem. Int. 2, 128, 2016.

12. ADAMCOVÁ D., VAVERKOVÁ M. D., STEJSKAL B., BROUSKOVA E. Household solid waste composition focusing on hazardous waste. Pol. J. Environ. Stud. 25, (2), 487, 2016.

13. DARGAHI A., GOLESTANIFAR H., DARVISHI P., KARAMI A., HASAN S. H., POORMOHAMMADI A., BEHZADNIA A. An investigation and comparison of removing heavy metals (lead and chromium) from aqueous solutions using magnesium oxide nanoparticles. Pol. J. Environ. Stud. 25 (2), 557, 2016.

14. DAUD M.K., HASSAN S., AZIZULLAH A., JAMIL M., REHAN N., IRUM R., QAISER M.K., ZHU S.J. Physiological, biochemical, and genotoxic effects of wastewater on maize seedlings. Pol. J. Environ. Stud. 25, (2), 563, 2016.

15. GHANEM K.M., AL-GARNI S.M., AL-ZAHRANI M.A. Bioremediation of diesel fuel by fungal consortium using statistical experimental designs. Pol. J. Environ. Stud. 25 (1), 97, 2016.

16. GHASEMI M.K., YUSUFF R.B.M. Advantages and disadvantages of healthcare waste treatment and disposal alternatives: Malaysian scenario. Pol. J. Environ. Stud. 25, (1), 17, 2016.

17. BABARINDE A., ONYIAOCHA G.O., Equilibrium sorption of divalent metal ions onto groundnut (Arachis hypogaea) shell: kinetics, isotherm and thermodynamics. Chem. Int. 2, 37, 2016.

18. ZHANG X., ZHAO Y., XU X., WANG C. Urbanization Effect on Energy-Related Carbon Emissions in Jiangsu Province from the Perspective of Resident Consumption. Pol. J. Environ. Stud. 26 (4), 1875, 2017.

19. BARSZCZ M. Influence of Applying Infiltration and Retention Objects to the Rainwater Runoff on a Plot and Catchment Scale - Case Study of Służewiecki Stream Subcatchment in Warsaw. Pol. J. Environ. Stud. 24 (1), 57, 2015.

20. CAO X., WU P., WANG Y., ZHAO X. Challenge of Water Sources in Urbanizing China: an Analysis of Agricultural Water Footprint. Pol. J. Environ. Stud. 24 (1), 9, 2015.

21. JAFARINEJAD S., Recent developments in the application of sequencing batch reactor (SBR) technology for the petroleum industry wastewater treatment. Chem. Int. 3, 241, 2017.

22. BABARINDE A., OGUNDIPE K., SANGOSANYA K.T., AKINTOLA B.D., ELIZABETH HASSAN A.-O., Comparative study on the biosorption of $\mathrm{Pb}(\mathrm{II}), \mathrm{Cd}(\mathrm{II})$ 
and $\mathrm{Zn}(\mathrm{II})$ using Lemon grass (Cymbopogon citratus): kinetics, isotherms and thermodynamics. Chem. Int. 2, 89, 2016.

23. OGUNDIPE K.D., BABARINDE A., Comparative study on batch equilibrium biosorption of $\mathrm{Cd}(\mathrm{II}), \mathrm{Pb}$ (II) and $\mathrm{Zn}$ (II) using plantain (Musa paradisiaca) flower: kinetics, isotherm, and thermodynamics. . Chem. Int. 3, 135, 2017.

24. IQBAL M., ABBAS M., ARSHAD M., HUSSAIN T., KHAN A.U., MASOOD N., TAHIR M.A., HUSSAIN S.M., BOKHARI T.H., KHERA R.A., Gamma radiation treatment for reducing cytotoxicity and mutagenicity in industrial wastewater. Pol. J. Environ. Stud. 24, 2745, 2015.

25. WANG Y., CHEN L., KUBOTA J. The relationship between urbanization, energy use and carbon emissions: evidence from a panel of Association of Southeast Asian Nations (ASEAN) countries. Journal of Cleaner Production, 112, 1368, 2016

26. WU Y., SHEN J., ZHANG X. The impact of urbanization on carbon emissions in developing countries: a Chinese study based on the U-Kaya method. Journal of Cleaner Production, 135, 589, 2016

27. HAN J., MENG X., ZHOU X., YI B.L., LIU M., XIANG W.N. A long-term analysis of urbanization process, landscape change, and carbon sources and sinks: A case study in Chinass Yangtze River Delta region. Journal of Cleaner Production, 141, 1040, 2017.

28. WANG Z., YANG Y. Features and influencing factors of carbon emissions indicators in the perspective of residential consumption: Evidence from Beijing, China. Ecological Indicators, 61, 634, 2016.

29. FENG K., HUBACEK K. Carbon implications of China's urbanization. Energy, Ecology and Environment, 1 (1), 39, 2016.

30. LIU Y., YAN B., ZHOU Y. Urbanization, economic growth, and carbon dioxide emissions in China: A panel cointegration and causality analysis. Journal of Geographical Sciences, 26 (2), 131, 2015.

31. AHMAD A., ZHAO Y., SHAHBAZ M. Carbon emissions, energy consumption and economic growth: An aggregate and disaggregate analysis of the Indian economy. Energy Policy, 96, 131, 2016.

32. WANG Y., XIE T., YANG S. Carbon emission and its decoupling research of transportation in Jiangsu Province. Journal of Cleaner Production, 142 (20), 907, 2016.

33. WANG C., WANG F., ZHANG X. Examining the driving factors of energy related carbon emissions using the extended STIRPAT model based on IPAT identity in Xinjiang. Renewable and Sustainable Energy Reviews, 67, 51, 2017.

34. AHIABLAME L.M., BERNARD A. E., INDRAJEET C. Effectiveness of low impact development practices in two urbanized watersheds: Retrofitting with rain barrel/ cistern and porous pavement. Journal of Environmental Management 119, 151, 2013.

35. EWALD J. A critique for phytosociology. J. Veg. Sci. 14, (2), 291, 2003.

36. COX W.G. Laboratory Manual of General Ecology. WMC Brown Co. Dubuque, IA, 1967.

37. CURTIS J.T., COTTAM G. Plant ecology works book. Laboratory field reference manual. Burgess publishing co. Minnesota, 1956

38. ALI S.I., QAISAR M. Flora of Pakistan. Pak. Agr. Res. Council Islamabad, 2010.

39. AHMED M., HUSSAIN T., SHEIKH A. H., HUSSAIN S.S., SIDDIQUI M.F. Phytosociology and Structure of
Himalayan Forests from Different Climatic Zones of Pakistan Pak. J. Bot. 38 (2), 361, 2006.

40. HABIB-UL-HASSAN, MURAD W., AHMAD N., TARIQ A., KHAN I., AKHTAR N., JAN S. Indigenous uses of the plants of Malakand valley, district Dir (Lower), Khyber Pakhtunkhwa, Pakistan. Pak. J. Weed Sci. Res. 21 (1), 83, 2015.

41. IBRAR M., HUSSANIN F., AMIR S. Ethnobotanical studies on plant resources of Ranyal Hills, District Shangla, Pakistan. Pak. J. Bot. 39, 329, 2007.

42. MALIK Z., SHOAIB H.M., RAFIQUE A.S., Malik N.Z. Phytosociology of some weeds of wheat communities around Kotli fields, Western Himalaya. J. Eco. Eniv. 5 (11), 340, 2013.

43. VOOGT J.A., OKE T.R. Thermal remote sensing of urban climates. Remote Sens. Environ. 86, 370, 2003.

44. ALI Q.M., WAZIR Y., KHAN M.H. Phytosociological studies of Azakhel, District Peshawar. Pak. J. For. 32 (1), 9, 1987.

45. CEMPEL M., NIKEL G. Nickel: a review of its sources and environmental toxicology. Pol. J. Environ. Stud. 15, 375, 2006.

46. PALIULIS D. Removal of formaldehyde from synthetic wastewater using natural and modified zeolites. Pol. J. Environ. Stud. 25 (1), 251, 2016.

47. ABBAS M., ADIL M., EHTISHAM-UL-HAQUE S., MUNIR B., YAMEEN M., GHAFFAR A., SHAR G.A., TAHIR M.A., IQBAL M., Vibrio fischeri bioluminescence inhibition assay for ecotoxicity assessment: A review. Sci. Total Environ. 626, 1295-, 2018.

48. AFTAB K., AKHTAR K., KAUSAR A., KHALIQ S., NISAR N., UMBREEN H., IQBAL M., Fungal strains isolation, identification and application for the recovery of $\mathrm{Zn}$ (II) ions. J. Photochem. Photobiol. B: Biol. 175, 182, 2017.

49. SZCZEPAŃSKA N., OWCZAREK K., KUDŁAK B., POKRYWKA A., MAZERSKA Z., GAŁUSZKA A., NAMIESNIK J. Analysis and Bioanalysis: an Effective Tool for Data Collection of Environmental Conditions and Processes. Pol. J. Environ. Stud. 25 (1), 45, 2016.

50. BIBI I., NAZAR N., IQBAL M., KAMAL S., NAWAZ H., NOUREN S., SAFA Y., JILANI K., SULTAN M., ATA S., REHMAN F., ABBAS M., Green and eco-friendly synthesis of cobalt-oxide nanoparticle: Characterization and photo-catalytic activity. Adv. Powder Technol. 28, 2035, 2017.

51. TANEE T., SUDMOON R., THAMSENANUPAP P., CHAVEERACH A. Effect of Cadmium on DNA Changes in Ipomoea aquatic Forssk. Pol. J. Environ. Stud. 25 (1), 311, 2016.

52. IQBAL M., BHATTI I.A., Gamma radiation $/ \mathrm{H}_{2} \mathrm{O}_{2}$ treatment of a nonylphenol ethoxylates: degradation, cytotoxicity, and mutagenicity evaluation. J. Hazard. Mater. 299, 351, 2015.

53. BENABDALLAH N.K., HARRACHE D., MIR A., DE LA GUARDIA M., BENHACHEM F.-Z., Bioaccumulation of trace metals by red alga Corallina elongata in the coast of Beni Saf, west coast, Algeria. Chem. Int. 3, 220, 2017.

54. IQBAL M., IQBAL N., BHATTI I.A., AHMAD N., ZAHID M., Response surface methodology application in optimization of cadmium adsorption by shoe waste: A good option of waste mitigation by waste. Ecol. Eng. 88, 265, 2016.

55. UKPAKA C., Development of model for bioremediation of crude oil using moringa extract. Chem. Int. 2, 19, 2016. 
56. NAZAR N., BIBI I., KAMAL S., IQBAL M., NOUREN S., JALANI K., UMAIR M., ATTA S., $\mathrm{Cu}$ nanoparticles synthesis using biological molecule of $\mathrm{P}$. granatum seeds extract as reducing and capping agent: Growth mechanism and photo-catalytic activity. Int. J. Biol. Macromol. 106, 1203, 2017.

57. TIAN F., LIU Y., LIU C., GU H., LIU H. Pollution status and multimedia fate simulation of phthalate acid esters (PAEs) in an arid city. Pol. J. Environ. Stud. 25 (1), 325, 2016.

58. FAIT S., FAKHI S., ELMZIBRI M., FAIZ Z., FOUGRACH H., BADRI W., SMOUNI A., FAHR M., Distribution of metallic trace elements (ETM) in surface soils around the mediouna discharge (southern of Casablanca). Chem. Int. 3, 278, 2017.

59. UKPAKA C., IZONOWEI T., Model Prediction on the Reliability of Fixed Bed Reactor for Ammonia Production. Chem. Int. 3, 46, 2017.

60. JAFARINEJAD S., Activated sludge combined with powdered activated carbon (PACT process) for the petroleum industry wastewater treatment: A review. Chem. Int. 3, 268, 2017.

61. NADEEM R., MANZOOR Q., IQBAL M., NISAR J., Biosorption of $\mathrm{Pb}$ (II) onto immobilized and native Mangifera indica waste biomass. J. Ind. Eng. Chem. 35, 185, 2016.

62. UKPAKA C., Empirical model approach for the evaluation of $\mathrm{pH}$ and conductivity on pollutant diffusion in soil environment. Chem. Int. 2, 267, 2016.
63. UL HAQ Z., JAMIL Y., IRUM S., RANDHAWA M.A., IQBAL M., AMIN N. Enhancement in the germination, seedling growth and yield of radish (Raphanus sativus) using seed pre-sowing magnetic field treatment. Pol. J. Environ. Stud. 21, 369, 2012.

64. LEGROURI K., KHOUYA E., HANNACHE H., EL HARTTI M., EZZINE M., NASLAIN R., Activated carbon from molasses efficiency for $\mathrm{Cr}(\mathrm{VI}), \mathrm{Pb}(\mathrm{II})$ and $\mathrm{Cu}$ (II) adsorption: A mechanistic study. Chem. Int. 3, 301, 2017.

65. UKPAKA C.P., IGWE F.U., Modeling of the velocity profile of a bioreactor: the concept of biochemical process. Chem. Int. 3, 258, 2017.

66. MAJOLAGBE A.O., ADEYI A.A., OSIBANJO O., Vulnerability assessment of groundwater pollution in the vicinity of an active dumpsite (Olusosun), Lagos, Nigeria. Chem. Int. 2, 232, 2016.

67. VARADARAJAN R, VENKATESAN G, SWAMINATHAN G. Removal of copper using clay admixed with quarry fines as landfill liners. Pol. J. Environ. Stud. 25 (1), 377, 2016.

68. MAJOLAGBE A.O., ADEYI A.A., OSIBANJO O., ADAMS A.O., OJURI O.O., Pollution vulnerability and health risk assessment of groundwater around an engineering Landfill in Lagos, Nigeria. Chem. Int. 3, 58, 2017. 